\title{
Modern Shoe Buckles from Archaeological Research in Gniew and Piaseczno (Pomerania Province, Poland)
}

\section{Introduction}

During archaeological research carried out from 2009 to 2016 in the Church of St. Nicholas in Gniew, a set of three metal buckles was found. Then, in 2017, excavations were conducted in the southern crypt of the Church of the Nativity of the Blessed Virgin Mary in the village of Piaseczno, in the Gniew District. Two other pairs of buckles were uncovered at this site. The buckles were analysed, restored, and documented, which involved their detailed description and measurement. On account of the diversity of buckles and a similar context of their discovery, it was decided that a comparison of shoe buckles would make a valuable contribution to studies on the character of the artefacts described below.

\section{Buckles as dress elements in the modern era}

Since antiquity, buckles have served functional purposes. With special straps made of leather or cloth they joined different elements of dress or gear (Wróblewska 2008: 200). In the modern era, they were frequently used to fasten belts, pattens, hats, trousers legs, armour, horse harness, and mostly shoes. Examples of such buckles have been found in many places in the territory of Poland including: Toruń (Grupa 2005; Drążkowska 2006; Bojarski 2013), Wrocław (Wachowski 1995; 2010; Konczewska, Konczewski 2004), Gdańsk (Ceynowa 2005; Bednarz 2016; Każdykrok... 2017), Warsaw (Blusiewicz 2009), Pułtusk (Drążkowska 2007), 
Szczuczyn (Grupa 20I2), the HMS General Carleton wreck (Wróblewska 2008), Stargard (Janowski 2016), and those described in this paper - Gniew (Grupa et al. 2015) and Piaseczno (Kulesz 2018; 2019).

\section{The origins and development of shoe buckles}

Even though buckles, sometimes called clasps, have been known since the Roman times, they only started to be used as shoe fastenings approximately in the twelfth century, which is indicated by shoes found during excavations in Lübeck (Goubitz, van Driel-Murray et al. 2001: 209). Throughout the Middle Ages and the Early Modern Era, they were usually used to fasten one or a few narrow straps on both high and low shoes. Such a fastening was placed on the side of the foot, and the buckle was fixed permanently to a fastening strap (Goubitz, van Driel-Murray et al. 200I: 2I2-2I8). Buckles of this type were manufactured by blacksmiths dealing with small items, and based on ceramic and stone moulds known from European cities (Willemsen, Ernst 2012: 39; Egan, Pritchard 2013: 105; Bednarz 2016: 268), such as Gdańsk (Majorek 2017), it can be presumed that they were not only forged but also cast. Iron buckles were most common, sometimes plated with tin or silver, however, some were also made of a tin and lead alloy. Also buckles made of a copper alloy - bronze or brass - are found (Ceynowa 2005: 323; Wachowski 2010: 244; Bednarz 2016: 268).

Over time, buckles on low shoes were moved to the central part of the instep, and they became larger and larger (Pratt, Woolley 2008: 29). Starting in the 1660s, an innovative use of buckles appeared. Metal buckles started to gradually supplant textile ornaments placed in the central part of the instep. These were usually lace rosettes $^{1}$ or monstrously big bows in strikingly different colours than the leather shoes or identical to the colour of the leather ${ }^{2}$ (Drążkowska 20II: 202-203). Buckles became the central ornament of the foot, drawing attention on account of the difference in colours between leather and metal, and over time they became more and more decorative ${ }^{3}$. Their production was taken over by jewellers, while users

I A portrait of Prince Janusz Radziwiłł (I632), painted by Dawid Bailly, National Museum in Wrocław (Dudziński et al. 20I5; Fig. 7).

2 This is perfectly exemplified by black shoes tied with black ribbons depicted in the painting of Frans Hals and Pieter Codde The company of Captain Reinier Reael and Lieutenant Cornelis Michielsz Blaeuw created in 1633-1637 (Pescio 2017: 32-33). Men wearing black wamses and knee breeches with black stockings are wearing such shoes. The only elements breaking the blackness are white ruffs. Of course, all types of fabric: silk, wool, and leather, despite their black colour, are clearly distinct in the painting as their textures reflect the light differently, which was perfectly captured by the authors.

3 However, in this case these were decorations of the surface and not new elements added to the buckle and increasing its weight as in monstrous textile ornaments. 


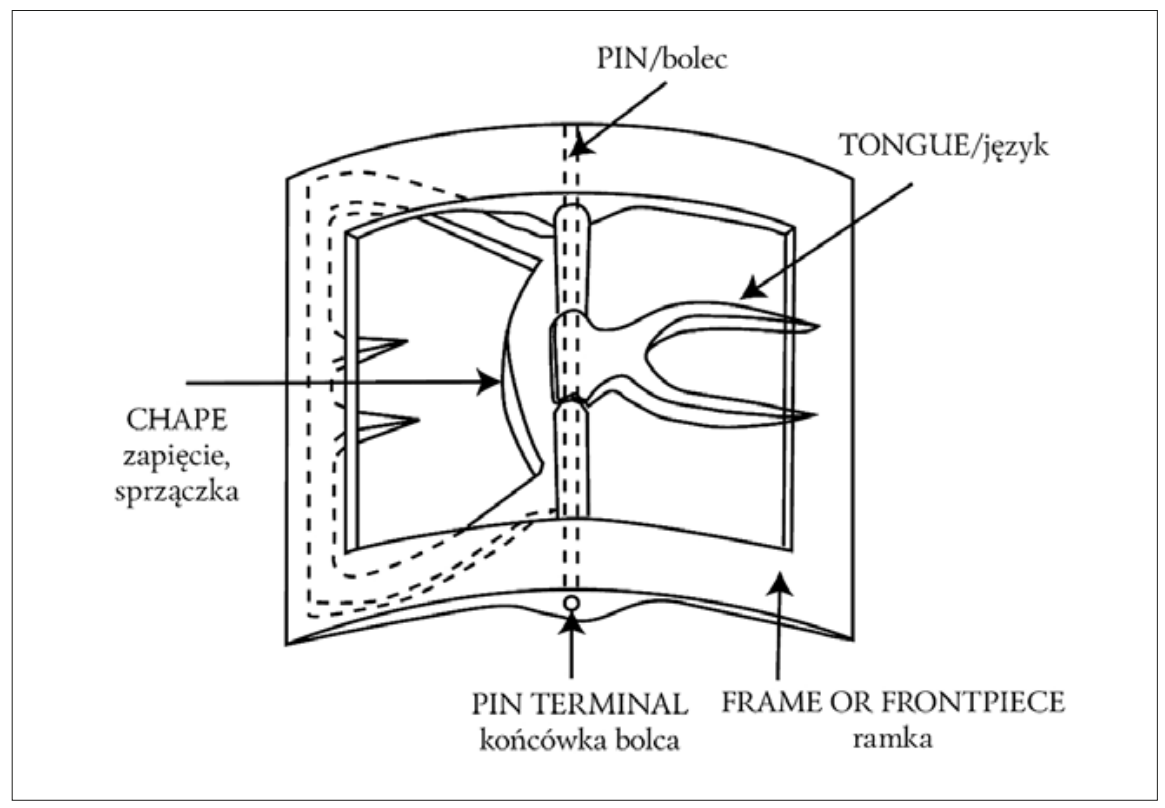

Fig. 1. The buckle structure and names of its elements according to Ewa Wróblewska (Wróblewska 2008: 202, Fig. 3).

started treating them as jewellery rather than integral elements of shoes (Pratt, Woolley 2008: 4I). Of course, buckles not made of precious metals and those without any special ornaments were still manufactured by blacksmiths and brassfounders. As the perception of buckles changed, their construction was modified and they were no longer fixed permanently to shoes. A pin with a tongue appeared (Fig. I), sometimes ending with a ball, which allowed to attach the buckle to a fastening strap and to unclasp it when needed (Swann 1982: 20; Goubitz, van Driel-Murray et al. 2001: 289, 291, Fig. Ia).

In the seventeenth century, buckles were still relatively small and their ornaments were rather simple, mostly geometrical (Pratt, Woolley 2008: 30; Whitehead 1996: I18). Decorative fastenings were made of different materials. The most expensive ones were made of silver and gold, and their surface was studded with jewels. Cheaper items were made of copper, tombac, and iron, and expensive jewels were replaced with rhinestones - diamond imitations, made of polished glass ${ }^{4}$ or

4 Buckles with polished glass were found in a crypt under the chancel of the Church of the Assumption of Mary in Toruń (Drążkowska 2006: 69-72). The crypt was created after the Tumult of Thorn in 1724 (Grupa 2005: 2I). It was the burial place of representatives of the local gentry wearing Polish dress and gentry women wearing Western dresses (or, in fact, their substitutes as for burial purposes they were sewn of the trains 


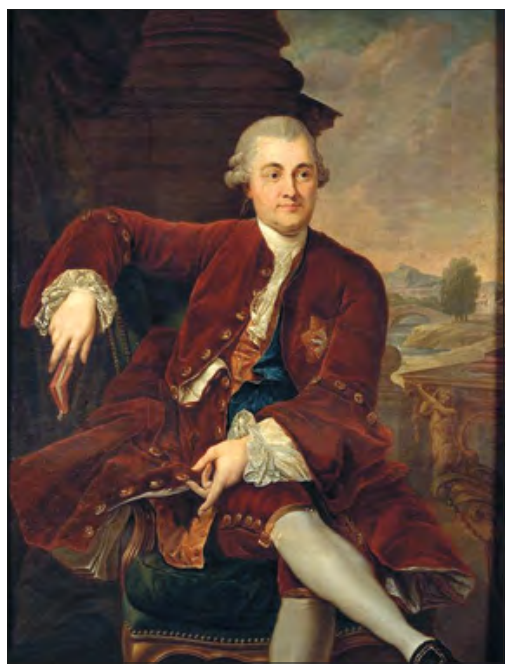

Fig. 2. An example of buckles on low shoes (Portrait of Kazimierz Poniatowski, Marcello Bacciarelli, c. I757, source: National Museum in Warsaw).

rock crystal (Whitehead 1996: i18; Boucher 2004: 28I, 283; Pratt, Woolley 2008: 4I). At the beginning of the eighteenth century, shoes became more massive, so their fastenings also evolved into larger, more massive forms (Swann 1982: 20). This resulted in a change in the way buckles were fastened as a single pin was not enough to secure them properly. Thus, a forked fastening was used (Whitehead 1996: I14) or a fastening in the shape of an anchor (Goubitz, van Driel-Murray et al. 2001: 290-291, Fig. Ib). In the eighteenth century, buckles became more and more decorative and larger and larger (Fig. 2), and in the 1770s, they were out of proportion to the shoe size, with some even covering the whole instep and half of the foot. Such impressive buckles made fastening straps wear more quickly, so they had to be regularly replaced (Pratt, Woolley 2008: 4I). Also the form of frame ornaments reached its peak in the eighteenth century - simple or openwork casts were used. Geometrical and floral designs could be combined to form sophisticated compositions following the current fashion (Boucher 2004: 28I). In the nineteenth century, buckle forms were simplified, and the fastening became triple (Whitehead 1996: II 4). It should be emphasised that buckles as ornaments of the front part of the shoe have never gone out of use.

\section{A description of buckles from Gniew and Piaseczno}

The first buckle from Gniew was found in the dirt floor in the southern crypt in St. Anna's Chapel in the Church of St. Nicholas. It is arched, and its shape resembles a rectangle (Fig. 3). It is $28 \mathrm{~mm}$ wide and $40 \mathrm{~mm}$ long. In the centre, to the left, it had a thickened area for an iron pin which was $1.5 \mathrm{~mm}$ in diameter. The width

of dresses worn by women when they were alive - Grupa 2005: 21, 62-63; 2019: 180182). It is presumed that the buckles excavated were elements of textile women's shoes similar to those found in museum collections (Drążkowska 20II: 252, 279). However, iconographic analysis indicates that such buckles were also worn by men, which is proved by full-length portraits of Louis XIV and Augustus II the Strong (MożdżyńskaNawotka 2002: II2; Grupa 2005: 77; Lachi 2011: 360). 


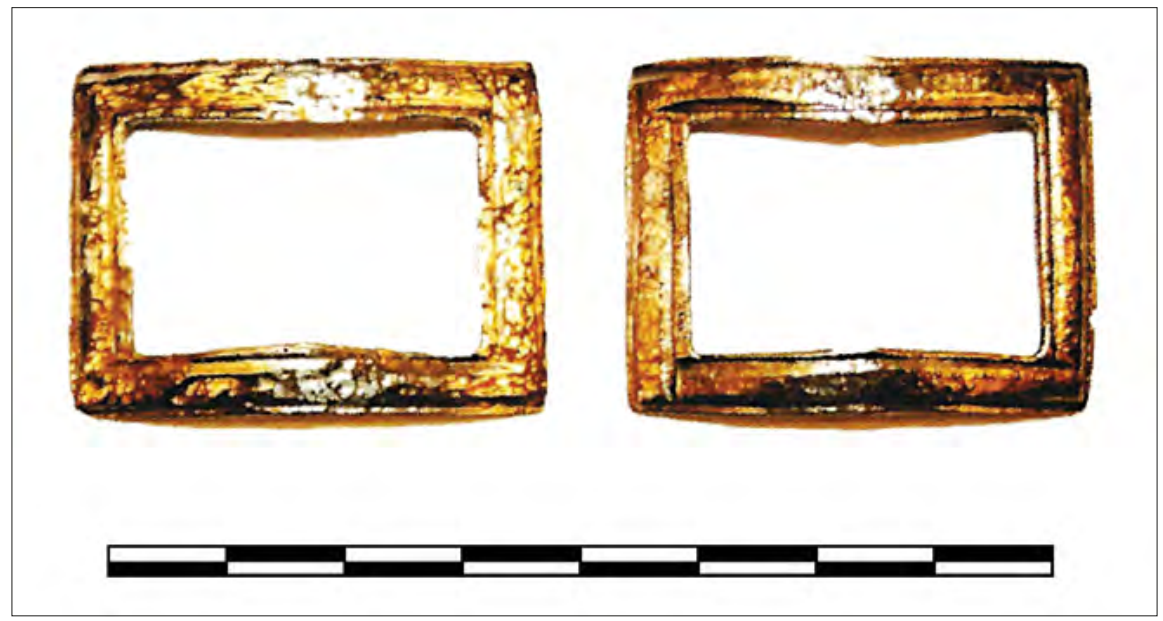

Fig. 3. Gniew, a shoe buckle made of a copper alloy, found in a crypt under St. Anna’s Chapel (Grupa et al. 2015: 146, Fig. I07).

of the tape the buckle was made of was 5-6 $\mathrm{mm}$. It was decorated in the simplest possible way, with shallow grooves along its outer and inner rims (Grupa et al. 2015: 145-I46). In the case of this buckle, remains of shoes have been preserved, which is why an attempt was made to identify the sex of the owner by comparing the sizes of soles found in the crypt with an average height of men and women in the Middle Ages. Thus, it can be said that it is highly probable that these were men's shoes of a larger size (Grupa et al. 2015: I47).

The other buckle, found during excavation in Gniew, just like the first one, came from the accumulation in the southern crypt. It is wholly made of iron and its shape and thickness suggest that it was forged of wire (Fig. 4). It is rec-

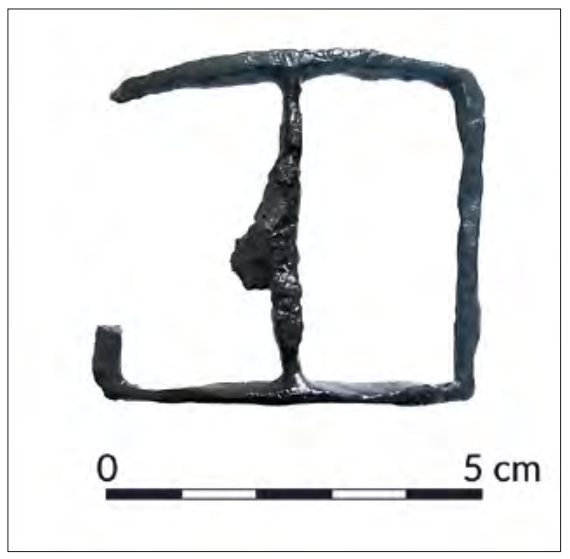
tangular in shape, and it is $50 \mathrm{~mm}$ long, $43 \mathrm{~mm}$ wide, and $2-4 \mathrm{~mm}$ thick. It is narrowest on shorter sides, where it is 2-3 mm thick, while its longer arched sides are $4 \mathrm{~mm}$ thick at the fastening pin mounting. The surface of the buckle is not decorated (Michalik 2017: 2).

Unfortunately, in the case of these two buckle types, fastening elements have not been preserved. Fastening

Fig. 4. Gniew, a shoe buckle made of an iron alloy, the southern crypt (photograph by J. Michalik). 

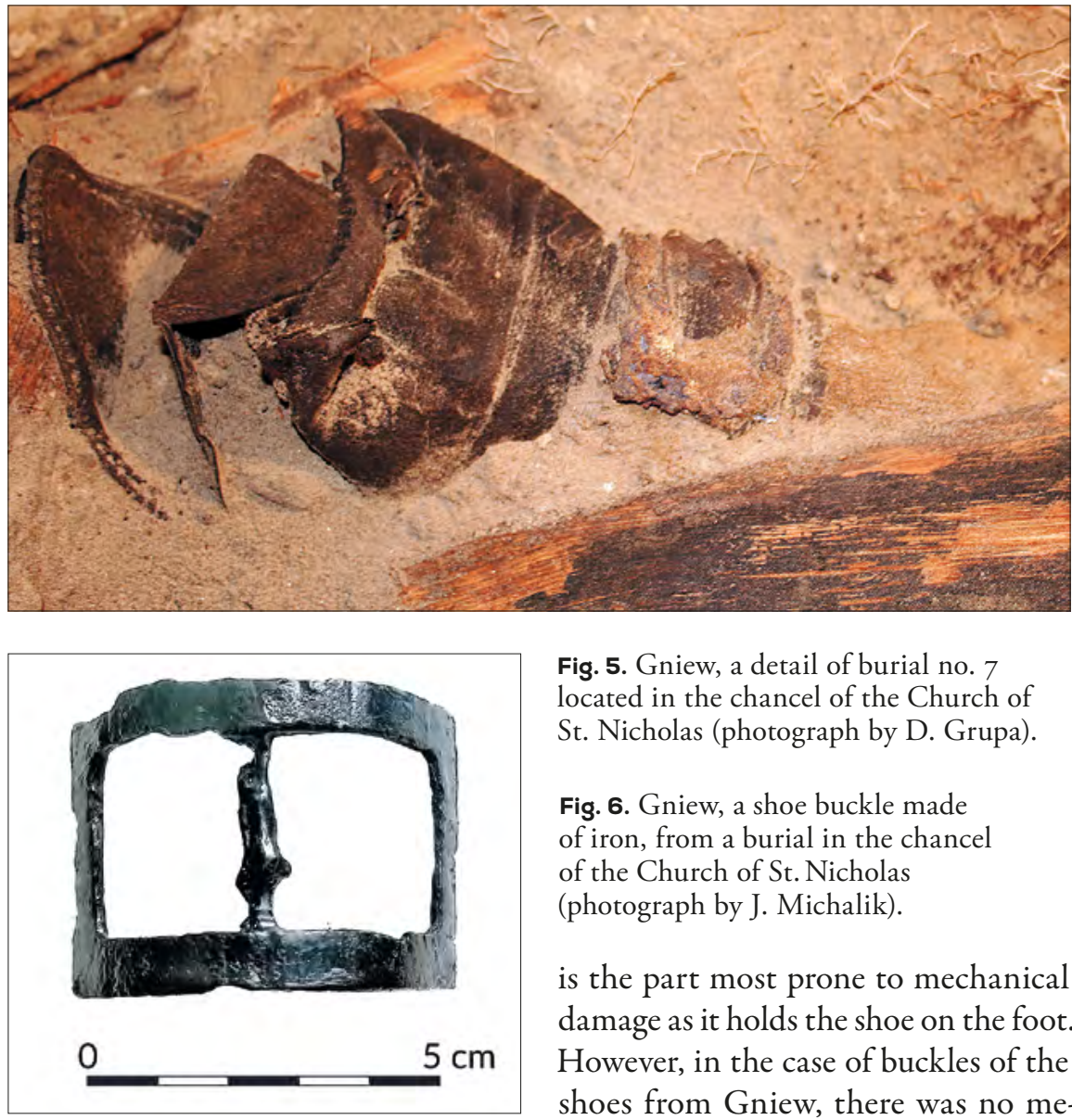

Fig. 5. Gniew, a detail of burial no. 7 located in the chancel of the Church of St. Nicholas (photograph by D. Grupa).

Fig. 6. Gniew, a shoe buckle made of iron, from a burial in the chancel of the Church of St. Nicholas (photograph by J. Michalik).

is the part most prone to mechanical damage as it holds the shoe on the foot. However, in the case of buckles of the shoes from Gniew, there was no mechanical damage as they were found in burials. Most probably, the fastenings corroded and fell apart as a result of the influence of organic matter (leather in this case) on the iron structure ${ }^{5}$.

The third of the buckles from Gniew was discovered during archaeological research in $201 \mathrm{r}$ along with the remains of a left shoe and human remains buried in the chancel of the church (Fig. 5). It does not differ from other buckles in shape: it is a rectangular frame, $70 \mathrm{~mm}$ long and $45 \mathrm{~mm}$ wide. The buckle was made of iron tape (Io mm wide). In the centre of the buckle there is a fastening with two teeth preserved, most probably made of $5 \mathrm{~mm}$ wide wire (Fig. 6). Moreover, similarly to other buckles, it was arched so as to fit the shape of the shoe. The buckle surface was smooth, without any ornaments (Michalik 2020b: 3 ).

5 In such combinations, iron gets destroyed first - Authors' observations. 


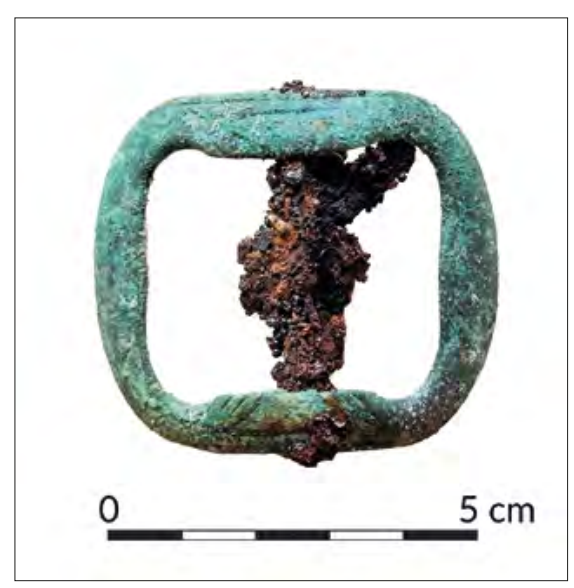

Fig. 7. Piaseczno, a shoe buckle made of a copper alloy, the southern crypt of the Church of the Nativity of the Blessed Virgin Mary (photograph by A. Kulesz).

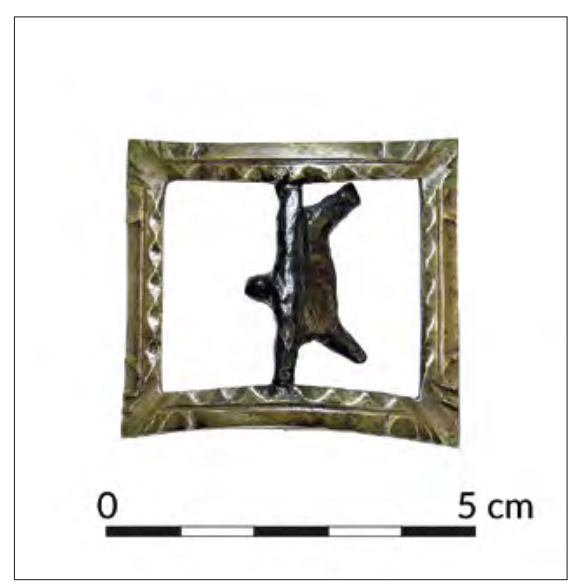

Fig. 8. Piaseczno, a shoe buckle made of a copper alloy with silver plating, the southern crypt of the Church of the Nativity of the Blessed Virgin Mary (photograph by J. Michalik).

The first two buckles from Piaseczno were nearly rectangular in shape, $60 \mathrm{~mm}$ long and $45 \mathrm{~mm}$ wide, with rounded apices. Their profile is emphasised by an internal opening with slightly wavy edges. Moreover, the buckles are arched and their surface is decorated with slight notches (Fig. 7). They were made of metal sheet, approx. I mm thick. The frames were made of a copper alloy, which is proved by the green colour of corrosion products on their surface. The pin dividing the buckle in half and the forked tongue fixed to it were most probably made of iron (Kulesz 2018: 85). The buckles were found as elements of well-preserved ankle-high shoes made of multiple fragments, with a quarter divided into two parts (Kulesz 2018: 79-80). Despite difficulties with finding similar buckles at other sites, a very similar buckle (only differing in ornamentation and size) was found on Granary Island in Gdańsk, in a levelling layer located behind the back wall of the 'Drey Sterne' granary, dated to the period between 1690 and 1790 (Bednarz 2016: 320).

The other pair of buckles from the crypt in Piaseczno were most probably made of a copper alloy (brass), plated with silver (Michalik 2020: II6) (Fig. 8). The frame was probably cut out of one rectangular piece of metal sheet, which was $50 \mathrm{~mm}$ long, $40 \mathrm{~mm}$ wide, and $3 \mathrm{~mm}$ thick. Just like in the case of other buckles, they are arched, and they are additionally decorated with cuts, notches, and grooves (Michalik 2020a: 3).

A majority of shoe buckles consist of two parts (with a movable fastening forming an axis), and so is the case with buckles from Gniew and Piaseczno, which 
can be classified into the group of two-part buckles with rectangular frames. However, despite a common feature, the buckles described differ considerably. Thanks to this, one can get an impression that apart from holding the shoe on the foot, they also served decorative purposes. One can distinguish two main types of buckles: those made of iron and those made of a copper alloy (Tab. I). The latter, considering ornaments, could be more valuable than their iron counterparts. Regardless of the alloy used, manufacturing techniques differed, some of which were those used in the case of buckles from Gniew and Piaseczno: wire forging, cutting out of thick metal sheet, and folding thin metal sheet.

What is curious is the use of different alloys for frames and fastenings. In the case of the two types of shoe buckles from Piaseczno, frames were made of a copper alloy (including one plated with silver) and fastenings were iron. Cases of using two different alloys to manufacture shoe buckles are known from, among others, a large collection found in the HMs General Carleton wreck (Wróblewska 2016: Fig. 6, 8, 9, II). The collection of more than 157 items includes both frames and fastenings made of iron and a copper alloy, so most probably there were no uniform rules of choosing alloys for frames and fastenings. This issue requires separate research on a much larger number of shoe buckles using archaeometric analysis.

Tab. 1. A comparison of buckles found during archaeological research in churches in Gniew and Piaseczno.

\begin{tabular}{|c|l|l|l|l|}
\hline No. & \multicolumn{1}{|c|}{ Location } & \multicolumn{1}{|c|}{ Buckle frame dimensions } & \multicolumn{1}{|c|}{ Material } & \multicolumn{1}{|c|}{ Ornamentation } \\
\hline 1 & Gniew & $\begin{array}{l}\text { Width: } 28 \mathrm{~mm} \text {, length: } 40 \mathrm{~mm}, \\
\text { tape width: } 5-6 \mathrm{~mm}\end{array}$ & Copper alloy & $\begin{array}{l}\text { Grooves along } \\
\text { the edge }\end{array}$ \\
\hline 2 & Gniew & $\begin{array}{l}\text { Width: } 43 \mathrm{~mm}, \text { length: } 50 \mathrm{~mm}, \\
\text { thickness: } 2-4 \mathrm{~mm}\end{array}$ & Iron alloy & None \\
\hline 4 & Gniew & $\begin{array}{l}\text { Width: } 45 \mathrm{~mm}, \text { length: } 70 \mathrm{~mm}, \\
\text { tape width: } 10 \mathrm{~mm}\end{array}$ & Iron alloy & None \\
\hline 5 & Piaseczno & $\begin{array}{l}\text { Width: } 60 \mathrm{~mm}, \text { length: } 45 \mathrm{~mm}, \\
\text { sheet thickness: } 1 \mathrm{~mm}\end{array}$ & $\begin{array}{l}\text { Copper alloy, fas- } \\
\text { tening of iron alloy }\end{array}$ & Notches, moulding \\
\hline
\end{tabular}

6 Based on the nomenclature used by Szymon Bednarz (2016: 269-270). 


\section{Characteristics of buckles from Gniew and Piaseczno}

The dimensions of all buckles described above clearly indicate their function: keeping shoes on feet. Shoes, however, were not the only dress elements fastened with buckles. Buckles were commonly used to fasten short trousers (breeches) at knee height (Boucher 2004: 283) and they were attached to leather and textile straps (Willemsen, Ernst 2012: 7-10, 100-103; Egan, Pritchard 2013: 50-I22). Buckles used for fastening trouser legs frequently corresponded with shoe buckles, together forming a set (Pratt, Woolley 2008: 4I). However, they were much smaller, and the buckle axle was usually fixed along its longer side (Whitehead 1996: I23).

The buckles from Gniew and Piaseczno are not richly ornamented or they have no ornaments whatsoever. Thus, it can be said they were rather cheap, which made them more popular among users from different social classes. Examples of such modest buckles were also found at other sites: in Gdańsk (Każdy krok... 2017: I24-I25) and among artefacts from the HMS General Carleton wreck (Wróblewska 2008: Fig. I, 6, 7, 9, I0, II).

It is much more difficult to explicitly determine the sex of the users of the artefacts described. Two of the buckles could be described as men's (no. I from Gniew and no. I from Piaseczno), which is mostly indicated by the size and the form of the shoes found with them. It is not certain in the case of other artefacts. Shoes fastened with buckles at the front were initially popular among men because women's dresses to the ground only revealed shoe toes. On account of this, buckles became elements of women's dress later, as the fashion trends changed (Swann 1982: 20; Pratt, Woolley 2008: 3I). An additional problem were sharp buckle edges that easily caught on and tore the fronts of long clothes (Pratt, Woolley 2008: 3I, 4I). It is generally assumed that women's buckles were smaller than men's, however, in the last quarter of the eighteenth century buckles became universal and those worn by men and women became identical (Pratt, Woolley 2008: 31, 4I; Whitehead 1996: II5).

It might be equally difficult to determine the chronology of the artefacts in question. In all likelihood they can be classified as artefacts from the eighteenth century. The dating of the buckle ${ }^{7}$ found along with low shoes in Piaseczno is least difficult as the form of the shoes indicates the second half of the eighteenth century (Kulesz 2018: 85). The situation is also rather clear in the case of brass artefacts with ornamented frames from Piaseczno, with which a fastening element with two pins has been preserved (thus, the shape, dimensions, and the fastening method all form an image typical of eighteenth-century buckles). The considerable size of buckle no. 3 from Gniew allows to unambiguously identify it as an artefact

7 In size, it corresponds with the buckle found on the leather shoes of Franciszek Schuldie, who died in 1782 in Szczuczyn (Dudziński et al. 20I5: 65-66, 88). 
also used in the second half of the eighteenth century. The other two buckles were found in an ossuary in the southern crypt, dated to the end of the first half of the eighteenth century, but they were buried already in the seventeenth century.

\section{Conclusions}

The described buckles from two neighbouring sites (the distance between the two towns is $6 \mathrm{~km}$ ) do not have any individual characteristics. It was impossible to determine any features that would suggest where the artefacts had been manufactured. However, it was observed that all buckles were rather modest in formal terms and that they were made of common metals. On account of their jewellery-like character, buckles could be bequeathed, and grave shoes were only fastened with tailor's pins (Kulesz 2019: 160; Grupa, Wojciechowska et al. 2013: I03, I56, Fig. 7) or put on the feet of the dead without fastening. This practice particularly concerned shoes with textile uppers ${ }^{8}$, which mostly meant women's shoes. It may suggest that the items in question were rather owned by men. The buckles described could be thus elements of the everyday attire. One should also bear in mind that no one placed the most expensive buckles in the grave', and - as the historic material from Gniew and Piaseczno indicates - the very presence of buckles among the clothes of the dead is rare.

It should also be emphasised that shoes fastened with central buckles were elements of the Western dress (Blusiewicz 2009: 72-79; Dudziński et al. 2015: 65). The canon of the Polish dress included completely different shoes, with uppers of a different length, without buckles or high heels. It is another reason to emphasise popularity of Western fashion in the territory of Pomerania in the eighteenth century, which is additionally confirmed by iconographic representations from the beginning of the seventeenth century onwards (Drążkowska 20II: 209-213; Grupa 2012: 117; Grupa, Wojciechowska et al. 2013: IOI).

Modern buckles found during archaeological research can pose numerous interpretive problems. They are usually found as independent items, unrelated to any specific pair of shoes. Naturally, this results from their use described above, which involved exchanging buckles between different pairs of shoes. In order to illustrate this, it is enough to mention that in the whole history of Dutch archaeological research until 20II, only one low shoe was found with a buckle still attached in its original position (Goubitz, van Driel-Murray et al. 2001: 289). In Poland,

8 Some of the textile shoes in museum collections have no buckles even though whole fastening straps have been preserved (Drążkowska 20II: 247, 250, 252, 267, 278).

9 However, there are known cases of burying the dead with highly ornamental buckles, decorated with imitations of expensive jewels and made of precious metals

(Drążkowska 2006: 69; 2007: 13-19). 
shoes with buckles are equally rare and they are found in specific conditions: in the case of burials in crypts and under the church floor (Kulesz 20r8; Dudziński et al. 2015: 65, 136, Fig. 38, 39). It should be once again emphasised that it was not a rule to bury the dead in shoes with buckles. Thus, the only indication allowing to determine the function of a buckle is its size and fastening method.

A separate issue is the dating of specific artefacts. Apart from the already described system of fastenings, there are no characteristics that would clearly indicate the chronology of the buckles. This indicator only allows to narrow down the dating to a century, however, it should be considered that the fastening element is not always preserved (usually, only the frame is available). This can be exemplified by the collection of buckles excavated from the HMs General Carleton wreck, in which most artefacts have no fastening elements (Wróblewska 2008: 199-200). Large size may suggest that buckles were manufactured in the second half of the eighteenth century, however, this does not mean that by a process of simple elimination it can be presumed that smaller objects are younger. Many of the buckles preserved with clear chronology show that small buckles were used throughout the eighteenth century and in the second half of the seventeenth century (Whitehead 1996: no. 757-765, no. 769). The buckle shape does not provide any clear indications either. Even though seventeenth-century buckles were frequently asymmetrical, and those from the eighteenth century were rectangular, in both these period a four-sided shape with rounded apices was popular. Descriptions of the shape of buckles were rarely connected with the determination of their purpose. There are still no clear terms that would denote shoe or belt buckles. Issues connected with a formal and typological interpretation of the buckles found indicate interpretive problems faced by archaeologists dealing with these aspects of costume studies. Modern shoes, due to the scarcity of artefacts in archaeological collections, remain mysterious and puzzling objects. Thus, it is important for the broadening of knowledge in this field to describe their structure and fastening elements including buckles.

\section{Bibliography}

Bednarz S. (2016), Sprzączki z wykopalisk przy ulicy Chmielnej 73-74 w Gdańsku, "Dantiscum", I, p. 267-334.

Blusiewicz K. (2009), Warsaw Footwear in the $14^{\text {th }}-18^{\text {th }}$ Century. From the Archaeological Collection in the Historical Museum of the City of Warsaw, Muzeum Warszawy, Warszawa (Archeologia Dawnej Warszawy, I).

Bojarski J. (2013), Badania archeologiczne prowadzone w Toruniu na stanowisku 577, na obszarze historycznego Przedmieścia Chetmińskiego, [in:] E. Fudzińska (ed.), XVIII Sesja 
Pomorzoznawcza, vol. II, Od późnego średniowiecza do czasów nowożytnych, Muzeum Zamkowe, Malbork, p. 22I-234.

Boucher F. (2004), Historia mody. Dzieje ubiorów od czasów prehistorycznych do końca $X X$ wieku, Arkady, Warszawa.

Ceynowa B. (2005), Patynki z badań na Wyspie Spichrzów w Gdańsku, [in:] H. Paner, M. Fudziński (ed.), XIV Sesja Pomorzoznawcza, vol. II, Od wczesnego średniowiecza do czasów nowożytnych, Muzeum Archeologiczne, Gdańsk, p. 319-326.

Drążkowska A. (2006), Klamry od butów wydobyte z krypty grobowej w kościele p.w. Wniebowzięcia Najświętszej Marii Panny w Toruniu, "Materiały do Dziejów Kultury i Sztuki Bydgoszczy i Regionu”, II, p. 69-72.

Drążkowska A. (2007), Srebrna klamra od buta z potowy XVIII wieku wydobyta z krypty grobowej w kościele p.w. św. Józefa w Puttusku, [in:] A. Henrykowska, R. Lolo (ed.), Puttuskie osobliwości. Materiaty wydane w roku obchodów 750-lecia nadania praw miejskich, Sarmatia Artistica, Warszawa, p. 13-19.

Drążkowska A. (2OII), Historia obuwia na ziemiach polskich od IX do końca XVIII wieku, Wydawnictwo Naukowe Uniwersytetu Mikołaja Kopernika, Toruń.

Dudziński T., Grupa M., Grupa D., Krajewska M., Majorek M., Nowak M., Nowak S., Przymorska-Sztuczka M., Wojciechowska A. (20I5), Tajemnice szczuczyńskich krypt, vol. III, Towarzystwo Przyjaciół 9 Psk. Uniwersytet Mikołaja Kopernika, Grajewo-Toruń.

Egan G., Pritchard F. (2013), Dress Accessories II50-I450, Boydell Press, London.

Goubitz O., Driel-Murray van C., Groenman-van Waateringe W. (200I), Stepping Through the Time. Archaeological Footwear From Prehistoric Times Until I80o, Stichting Promotie Archeologie, Zwolle.

Grupa M. (2005), Ubiór mieszczan i szlachty z XVI-XVIII wieku z kościoła p.w. Wniebowzięcia Najświętszej Marii Panny w Toruniu, Wydawnictwo Uniwersytetu Mikołaja Kopernika, Toruń.

Grupa M. (20I2), Pochówki w krypcie grobowej kościota p.w. Imienia NMP w Szczuczynie jako źródto do lokalnych badań kostiumologicznych, [in:] T. Dudziński (ed.), Pozaarchiwalne materiaty źródtowe do dziejów powiatu szczuczyńskiego w XIX wieku, Towarzystwo Przyjaciół 9 PSK, Grajewo, p. I09-I25.

Grupa M. (2019), Not Only Socks Were Darned: Secondary Textile Usage as a Source of Material Culture Studies, "Fasciculi Archaeologiae Historicae", 32, p. 165-187, https://doi.org/I0.23858/FAH32.2019.0II

Grupa M., Wojciechowska A., Dudziński T. (2013), W czym do trumny - żupany, kontusze, dezabilki $i$ inne ubiory pochowanych w szczuczyńskich kryptach, [in:] T. Dudziński, M. Grupa (ed.), Tajemnice szczuczyńskich krypt, vol. I, Towarzystwo Przyjaciół 9 Psк, Grajewo, p. 99-I08.

Grupa M., Kozłowski T., Jankauskas R., Grupa D., Krajewska M., Krakowska S., Majorek M., Mosiejczyk J., Nowak M., Nowak S., Przymorska-Sztuczka M., Wojciechowska A. (2015), Secrets of the Crypt in St.Ann's Chapel. Tajemnice krypty w kaplicy sw. Anny, Gniew.

Janowski A. (2016), Zabytki metalowe, [in:] M. Majewski (ed.), Archeologia Stargardu. Badania na obszarze dawnego kościota augustiańskiego, vol. II.2, Muzeum Archeologiczno-Historyczne, Stargard, p. 293-355. 
Każdy krok zostawia ślad. Obuwie historyczne ze zbiorów Muzeum Archeologicznego w Gdańsku. Katalog wystawy (20I7), B. Ceynowa, E. Trawicka (ed.), Muzeum Archeologiczne, Gdańsk.

Konczewska M., Konczewski P. (2004), Zabytki metalowe z fosy miejskiej we Wroctawiu, [in:] J. Piekalski, K. Wachowski (ed.), Wroctaw na przetomie średniowiecza i czasów nowożytnych. Materialne przejawy życia codziennego, Uniwersytet Wrocławski, Wrocław (Wratislavia Antiqua, 6), p. 89-205.

Kulesz A. (2018), Męskie obuwie niskie z badań w kościele pw. narodzenia NMP w Piasecznie, gm. Gniew, "Rydwan", I3, p. 79-88.

Kulesz A. (2019), Women's Shoes From the Crypt of the Church of the Name of the Holy Virgin Mary in Szczuczyn, Podlaskie Voivodship, "Analecta Archaeologica Ressoviensia", I4, p. I55-I68.

Lachi Ch. (20II), Sztuka Baroku, Arkady, Warszawa (Wielka Historia Sztuki, 5).

Majorek M. (20I7), Raport prac konserwatorskich i restauratorskich. Forma odlewnicza ( $\mathrm{Nr}$ inw. Iw 665/2016) (a manuscript in the archive of the Laboratory of Monument Documentation and Conservation of the Nicolaus Copernicus University in Toruń).

Michalik J. (20I7), Dokumentacja konserwatorska. Konserwacja klamry buta ze stanowiska Gniew, gm. Loco (nr inw. 4/II) (a manuscript in the archive of the Laboratory of Monument Documentation and Conservation of the Nicolaus Copernicus University in Toruń).

Michalik J. (2020), Pomiar hydrostatyczny i konserwacja metalowej klamry do buta z Piaseczna, "Rydwan", I5, p. IO2-III.

Michalik J. (2020a), Dokumentacja konserwatorska. Konserwacja klamry buta ze stanowiska Piaseczno, gm. Gniew (nr inw. 25/20I7) (a manuscript in the archive of the Laboratory of Monument Documentation and Conservation of the Nicolaus Copernicus University in Toruń).

Michalik J. (2020b), Dokumentacja konserwatorska. Konserwacja klamry buta ze stanowiska Gniew, gm. Loco (nr inw. 19/og) (a manuscript in the archive of the Laboratory of Monument Documentation and Conservation of the Nicolaus Copernicus University in Toruń).

Możdżyńska-NawotkaM. (2002), O modachi strojach, Wydawnictwo Dolnośląskie, Wrocław. Pescio C. (20I7), Malarstwo holenderskie. Ztoty wiek, trans. A. Kłos, Arkady, Warszawa.

Pratt L., Woolley L. (2008), Shoes, v \& A Pub., London.

Swann J. (1982), Shoes, B.T. Batsford, London.

Wachowski K. (1995), Sprzączki profilowane z terenu Ślaska, "Studia Archeologiczne”, 26, p. 247-25I.

Wachowski K. (2010), Kultura materialna publicznej przestrzeni miasta w świetle zabytków ruchomych. Sprzaczki, [in:] J. Piekalski, K. Wachowski (ed.), Ulice średniowiecznego Wroctawia, Uniwersytet Wrocławski. Instytut Archeologii, Wrocław (Wratislavia Antiqua, II), p. 242-244.

Whitehead R. (1996), Buckles I250-1800, Greenlight Publishing, Witham.

Willemsen A., Ernst M. (2012), Middeleeuwse mode in metaal. Sierbeslag op rieman en tassen uit de Nederlanden 1300-I600, Groningen.

Wróblewska E. (2008), Buckles From Shoes and Clothing. Klamry do butów i odzieży, [in:] W. Ossowski (ed.), The General Carleton Shipwreck, I785. Wrak statku General Carleton, I785, Polish Maritime Museum, Gdańsk, p. I99-2I2. 


\section{Summary}

\section{Modern Shoe Buckles from Archaeological Research in Gniew and Piaseczno (Pomerania Province, Poland)}

During archaeological research carried out from 2009 to 2016 in the Church of St. Nicholas in Gniew, a set of three metal buckles was found. Then, in 2017, excavations were conducted in crypts of the Church of the Nativity of the Blessed Virgin Mary in the village of Piaseczno, in the Gniew District. Two other pairs of buckles were uncovered at this site. All the buckles found differ considerably. Thanks to this, one can get an impression that apart from holding the shoe on the foot, they also served decorative purposes. One can distinguish two main types of buckles: those made of iron and those made of a copper alloy. The latter, considering ornaments, could be more valuable than their iron counterparts. Regardless of the alloy used, manufacturing techniques differed, some of which were those used in the case of buckles from Gniew and Piaseczno: wire forging, cutting out of thick metal sheet, and folding thin metal sheet.

On account of their jewellery-like character, this small collection of buckles discussed could be bequeathed, while most grave shoes were only fastened with tailor's pins or put on the feet of the dead without fastening. This practice particularly concerned shoes with textile uppers, which mostly meant women's shoes. It may suggest that the items in question were rather owned by men. The buckles described could be thus elements of the everyday attire.

Issues connected with a formal and typological interpretation of the buckles found indicate interpretive problems faced by archaeologists dealing with these aspects of costume studies. Modern shoes, due to the scarcity of artefacts in archaeological collections, remain mysterious and puzzling objects.

Keywords: shoe buckle, shoe clasp, archaeology, shoes, modern era, Gniew, Piaseczno, funeral culture

\section{Streszczenie}

\section{Nowożytne klamry do butów z badań archeologicznych w Gniewie i Piasecznie (woj. pomorskie)}

W trakcie badań archeologicznych prowadzonych w latach 2009-2016 w kościele pw. św. Mikołaja w Gniewie pozyskano zespół trzech klamer metalowych. Następnie w 2017 r. przeprowadzono badania wykopaliskowe w kryptach kościoła pw. Narodzenia Najświętszej Marii Panny we wsi Piaseczno, należącej do gminy Gniew. Na stanowisku tym odkryto dwie kolejne pary klamer. Wszystkie znalezione klamry znacznie różnią się od siebie. Dzięki temu można odnieść wrażenie, że prócz trzymania buta na stopie, pełniły również funkcję dekoracyjną. Wyróżnić można dwa główne rodzaje klamer - wykonane z żelaza i ze stopu miedzi. Te drugie, sądząc po obecności zdobienia, mogły być bardziej wartościowe od ich odpowiedników ze stopu żelaza. Niezależnie od zastosowanego stopu korzystano z różnych technik ich produkcji, spośród których wymienić można te użyte 
w przypadku klamer z Gniewu i Piaseczna: kucie z drutu, wycinanie z kawałka grubej blachy i wywijane z cienkiej blachy.

Zbiór omawianych sprzączek, pochodzących z dwóch sąsiadujących z sobą stanowisk (odległość pomiędzy miejscowościami wynosi $6 \mathrm{~km}$ ), nie wykazał żadnych cech charakterystycznych dla poszczególnych egzemplarzy. Nie udało się ustalić żadnych wyróżników, które mogłaby sugerować miejsce wykonania omawianych artefaktów. Zaobserwowano jednak, że wszystkie sprzączki są dość skromne formalnie, a wszystkie też zostały wykonane z popularnych metali. Z uwagi na biżuteryjny charakter klamry mogły być przekazywane w spadku, a obuwie grobowe zapinane było tylko szpilkami krawieckimi lub nasuwane na stopę zmarłego bez zapięcia. Praktyka ta odnosi się w szczególności do obuwia, którego wierzchy wykonane zostały z tkanin, czyli przede wszystkim damskiego. Może to sugerować, że omawiane egzemplarze raczej należały do mężczyzn. Opisywane klamry mogły zatem stanowić element ubioru codziennego.

Zagadnienia związane z interpretacją formalno-typologiczną znalezionych klamerek wskazują, z jakimi trudnościami interpretacyjnymi stykają się archeolodzy zajmujący się tymi aspektami kostiumologii. Obuwie z okresów nowożytnych z uwagi na niewielką ilość występowania w kolekcjach archeologicznych jest w dalszym ciągu materiałem tajemniczym i zagadkowym.

Słowa kluczowe: klamra do butów, sprzączka do butów, archeologia, buty, epoka nowożytna, Gniew, Piaseczno, kultura pogrzebowa

\author{
Aleksandra Kulesz \\ Nicolaus Copernicus University in Toruń \\ Institute of Archaeology \\ Poland \\ e-mail: olina.kulesz@gmail.com
}

\title{
Jakub Michalik
}

Nicolaus Copernicus University in Toruń

Institute of Archaeology

Poland

e-mail: michalik@doktorant.umk.pl 